\title{
KLONING GEN FIM-C SALMONELLA TYPHIMURIUM DENGAN VEKTOR PGEM-T easY UNTUK PENGEMBANGAN VAKSIN REKOMBINAN PENYAKIT TYPHUS PADA MANUSIA
}

\author{
Muktiningsih Nurjayadi ${ }^{1,3}$, Giri Alviyanto ${ }^{1,3}$, Fera Kurnia Dewi ${ }^{1,3}$, Irma Ratna Kartika ${ }^{1,3}$, Fernita Puspasari ${ }^{2}$, dan \\ Dessy Natalia ${ }^{2}$ \\ 1 Jurusan Kimia UNJ, Fakultas Matematika Ilmu Pengetahuan Alam. Universitas Negeri Jakarta Jl. Pemuda No. \\ 10 Rawamangun Jakarta Indonesia \\ 2 Program Studi Kimia ITB, Bandung, Indonesia \\ ${ }^{3}$ Laboratorium Bioteknologi Fakultas Matematika Ilmu Pengetahuan Alam Universitas Negeri Jakarta. Jl. \\ Pemuda No. 10 Rawamangun Jakarta Indonesia
}

Corresponding Author: mutinurjayadi@yahoo.com

\begin{abstract}
Abstrak
Bakteri Salmonella typhimurium merupakan penyebab penyakit typhus pada hewan mencit. Bakteri ini sering digunakan sebagai model untuk mempelajari penyakit typhus pada manusia. Penelitian ini bertujuan mendapatkan klon rekombinan gen fim-C Salmonella typhimurium dengan ukuran 0,7 kilobasa (pGEM-TStpm-fim-C) dan mengetahui karakteristik gen fim-C Salmonella typhimurium hasil kloning tersebut. Metode yang digunakan pada penelitian ini adalah metode eksploratif. Tahap yang dilakukan meliputi isolasi DNA genom S. typhimurium, amplifikasi gen fim-C S. typhmurium dengan metode PCR, karakterisasi gen fim-C S. typhimurium hasil amplifikasi, purifikasi gen fim-C S. typhimurium, kloning gen fim-C S. typhimurium dengan vektor pGEM-T easy, dan karakterisasi hasil kloning. Amplifikasi gen fim-C dengan metode PCR menggunakan primer FimC-Stpm-F dan FimC-Stpm-R menghasilkan pita DNA berukuran 0,7 kilobasa sesuai ukuran gen fim-C S. typhimurium. Kesesuaian tersebut menunjukkan bahwa desain dan sintesis primer serta amplifikasi berhasil dilakukan. Hasil kloning gen fim-C S. typhimurium 0,7 kb dengan vektor kloning pGEM-T easy memberikan koloni putih dan biru dengan ukuran yang sesuai stándar. Analisis restriksi plasmid rekombinan pGEM-T-Stpmfim-C dengan enzim BamHI dan HindIII menghasilkan dua pita berukuran 3 kb dan 0,7 kb sesuai ukuran DNA vektor pGEM-T easy dan gen fim-C S. typhimurium sebagi insert. Sekuensing klon rekombinan yang dihasilkan membuktikan bahwa urutan DNA S. typhimurium yang diperoleh memiliki homologi sebesar $99 \%$ dengan S.typhimurium LT2 pada GeneBank. Berdasarkan data-data tersebut disimpulkan bahwa pada penelitian ini telah berhasil dilakukan kloning gen fim-C S. typhimurium berukuran 0,7 kb pada vektor pGEM-T easy.
\end{abstract}

Kata kunci : Salmonella typhimurium, kloning gen fim-C S. typhimurium, vaksin rekombinan, penyakit typhus.

\begin{abstract}
Salmonella typhimurium is bacteria that causes typhus disease in mouse. Usually, Salmonella typhimurium is used as a model for typhus disease study in human. The research is aimed to obtain recombinant clone of Salmonella typhimurium fim-C gene 0.7kilobase (kb) and knowing characteristics of Salmonella typhimurium gene the cloning result. Method of this research is exploration. Step of this research are isolate DNA genome of $S$. typhimurium bacteria, amplificate fim-C gene by $P C R$, characterize S.typhimurium fim-C the amplification product, purification of S.typhimurium fim-C gene, cloning of S.typhimurium fim-C gene with pGEM-T easy vector, characterize the cloning product. Amplification of fim-C gen by PCR used FimC-Stpm- $F$ primer and FimC-Stpm-R primer produce DNA band 0.7kilbase appropriate with size of S.typhimurium fim-C gene. This result showing design, primer synthesis, and amplification has been succesfully. The cloning result from S.typhimurium fim-C gene $0.7 \mathrm{~kb}$ with cloning vector $\mathrm{PGEM}-\mathrm{T}$ easy give white colony and blue colony. The restriction analysis of recombinant plasmid pGEM-T-Stpm-fim-C with BamHI and HindIII enzyme produces two band $3 \mathrm{~kb}$ and $0.7 \mathrm{~kb}$ which appropriate size of DNA pGEM-T-easy vector and S.typhimurium fim-C gene as insert. Sequencing of recombinant clone proving DNA S.typhimurium have 99\% homolog with S.typhimurium LT2 in GeneBank. Conclusión this research is cloning of S.typhimurium fim-C gene 0.7kb with pGEM-T easy has been succesfully.
\end{abstract}

Keywords: Salmonella typhimurium, cloning of Salmonella typhimurium fim-C gene, recombinant vaccine, typhus disease.

\section{PENDAHULUAN}

Penyebab penyakit typhus adalah Salmonella typhi yang habitatnya pada manusia. Sehingga diperlukan model binatang untuk mempelajari patogenesis bakteri tersebut. Kurangnya atau tidak adanya model 
binatang yang cocok (yang lebih tinggi dari primata) untuk S. typhi dengan habitat yang memiliki spesifisitas seperti manusia merupakan hambatan yang signifikan untuk mempelajari patogenesis $S$. typhi dan untuk menguji vaksin yang aman dan efektif melawan demam typhus. Oleh karena itu, untuk mempelajari patogenesis demam typhus digunakan Salmonella typhimurium dengan menggunakan model binatang mencit [6].

Fimbriae adalah protein permukaan yang terdapat pada bakteri gram positif dan gram negatif termasuk S. typhimurium. Fimbriae ini digunakan untuk menempelkan dirinya pada sel inangnya dan beberapa objek lainnya. Beberapa ciri-ciri telah dapat dikaji dan disimpulkan bahwa fimbriae pada S. typhi dan S. typhimurium memiliki peranan pada pertahan bakteri dalam sel inangnya atau pada lingkungan eksternal [7]. Kemampuan menempel tersebut didukung oleh dimilikinya berbagai komponen pendukung seperti flagella dan filli/fimbriae yang berfungsi menembus barrier sel epitel dan menyerang sel inang.

Sebanyak 148-200 orang/100.000 penduduk Indonesia pada tahun 2002 [5] dan 358-810 orang/100.000 penduduk Indonesia pada tahun 2007 menderita demam typhus [4]. Melihat meningkatnya angka morbiditas tersebut maka diperlukan suatu alternatif untuk penanganan atau pencegahan penyakit typhus. Alternatif yang diperlukan untuk pencegahan penyakit typhus adalah dengan menggunakan vaksin. Saat ini vaksin yang digunakan untuk pencegahan typhus adalah vaksin Ty21a (oral) dan vaksin Vi CPS (suntik). Namun, vaksin ini memiliki kelemahan dimana akan mengalami penurunan efektivitas perlindungannya pada penyakit typhus jika daerah tersebut merupakan daerah hiperendemik seperti Indonesia. Kelemahan lainnya adalah hanya dapat digunakan pada orang dewasa dan anak-anak usia 6 tahun atau lebih, serta harus dilakukan pengulangan setiap 5 tahun. Vaksin-vaksin tersebut ternyata juga memiliki efek samping pada penggunanya dan tidak efisien, karena dibutuhkan pengulangan vaksinasi. Efek samping yang dialami oleh orang yang mendapatkan vaksin adalah mual, muntah, rasa tidak nyaman di perut, demam, dan sakit kepala. Oleh karena itu, dibutuhkan vaksin yang lebih aman dan efisien [2].

Melihat luasnya penyebaran dan banyaknya pasien typhus, maka vaksin rekombinan ini akan sangat membantu dalam mengatasi permasalahan yang ada. Berdasarkan hal tersebut maka penelitian ini penting untuk dilaksanakan. Penelitian yang dilaporkan ini merupakan tahap awal dalam pembuatan vaksin rekombinan yang aman dan efisien, dengan tujuan mendapatkan klon rekombinan dengan cara kloning gen fim- $\mathrm{C}$ Salmonella typhimurium dan karakterisasi hasil kloningnya.

\section{METODOLOGI PENELITIAN}

Perancangan dan Sintesis Primer Fimbrial-C dengan Penambahan Urutan Nukleotida Pengode Histidin

Primer spesifik yang digunakan pada penelitian ini didesain langsung dari urutan gen fim-C S.typhimurium penelitian sebelumnya. Primer yang digunakan merupakan satu buah rancangan primer forward (FimC-Stpm-F) dan satu buah rancangan primer reverse (FimC-Stpm-R). Primer tersebut sebelumnya ditambahkan sepuluh asam amino pengode histidin dan urutan nukleotida pengenal enzim restriksi Hind III pada ujung 3' sedangkan pada ujung 5 ' ditambahkan urutan nukleotida pengenal enzim restriksi $B a m \mathrm{H}$ I. Untuk sintesis primer dilakukan oleh First-Base Laboratory Korea.

Penumbuhan Biakan Bakteri S. typhimurium di Laboratorium Biokimia FMIPA UNJ

Bakteri yang digunakan pada penelitian ini adalah bakteri S. typhimurium galur lokal yang 
Tabel 1. Primer Gen fim-C S. typhimurium Berukuran 0,7 Kilobasa

\begin{tabular}{|c|c|c|c|c|c|c|}
\hline No. & Primer & Sekuens & Skala & $\% G \mathrm{C}$ & $\mathrm{TM}^{0} \mathrm{C}$ & MW \\
\hline 1. & $\begin{array}{l}\text { FimC- } \\
\text { Stpm-F }\end{array}$ & $\begin{array}{c}\text { 5'- GGA TCC AAA AAA AAC GTA } \\
\text { CCG ATT TTC CTT CG - } 3^{\prime}\end{array}$ & $\begin{array}{l}0,05 \\
\mu \mathrm{mol}\end{array}$ & 40,6 & 70,0 & $9.786,1$ \\
\hline 2. & $\begin{array}{l}\text { FimC- } \\
\text { Stpm-R }\end{array}$ & $\begin{array}{c}5^{\prime}-\text { AAG CTT TCA TGA AGC TGG } \\
\text { ACA AAC GCG TG -3' }\end{array}$ & $\begin{array}{l}0,05 \\
\mu \mathrm{mol}\end{array}$ & 48,3 & 70,4 & $8.968,0$ \\
\hline
\end{tabular}

diperoleh dari Laboratorium Mikrobiologi FK-UI selanjutnya bakteri tersebut dibiakkan dan diremajakan di Laboratorium BiokimiaBioteknologi FMIPA UNJ sebagai bakteri uji.

Pembiakan Bakteri S. typhimurium pada Media Nutrient Broth Cair

Pelaksanaan peremajaan bakteri-bakteri pada penelitian ini ditempuh cara sebagai berikut: biakan bakteri pada agar miring diambil dengan kawat ose steril (satu koloni atau gores ose). Kemudian kawat ose steril yang telah ditempelkan pada bakteri dicelupkan pada $5 \mathrm{~mL}$ media Nutrient broth cair steril yang telah ditempatkan pada tabung reaksi. Selanjutnya diinkubasi pada suhu $37^{\circ} \mathrm{C}$ selama 16-18 jam dengan aerasi shaker sebesar $150 \mathrm{rpm}$. Hasil penumbuhan bakteri dicek dengan melihat kekeruhan yang timbul.

Pembiakan Bakteri S. typhimurium pada Nutrient Agar

Kawat ose steril dicelupkan pada biakan bakteri cair hasil penumbuhan pada tahap sebelumnya. Selanjutnya kawat ose tersebut digoreskan dengan cara zig-zag pada media nutrient agar steril yang telah disiapkan. Media nutrient agar yang telah mengandung bakteri diinkubasi 16-18 jam pada inkubator pada suhu $37{ }^{\circ} \mathrm{C}$. Hasil penumbuhan bakteri di cek setelah proses inkubasi selama 16-18 jam.

Isolasi Genom S. typhimurium dan Karakterisasinya

Tahapan yang ditempuh untuk proses isolasi DNA genom bakteri mengikuti kit isolasi wizard dari promega. Volume kultur bakteri yang diisolasi adalah $3 \mathrm{~mL}$. Hasil isolasi kemudian disimpan pada suhu $2-8^{\circ} \mathrm{C}$. Hasil i solasi dikarakterisasi dengan elektroforesis gel agarosa $1 \%$ dengan pewarna (pemendar warna saat terkena sinar UV) etidium bromida. Masing-masing $5 \mu \mathrm{L}$ DNA genom dicampurkan dengan $1 \mu \mathrm{L}$ loading dye buffer (buffer pewarna). Proses elektroforesis dilakukan pada kondisi 80 volt selama 1 jam. Visualisasi hasil elektroforesis dilakukan di bawah lampu UV dengan panjang gelombang $260 \mathrm{~nm}$.

Amplifikasi Genom S. typhimurium dengan PCR dan Karakterisasinya

Pada penelitian ini amplifikasi DNA genom dilakukan dengan mesin thermal cycle, pasangan primer fimC-Stpm- $F$ (5'-GGA TCC AAA AAA AAC GTA CCG ATT TTC CTT CG-3') dan primer fimC-Stpm-R (5'-AAG CTT TCA TGA AGC TGG ACA AAC GCG TG-3'), nuclease free water, serta Master Mix PCR. Total reaksi sebanyak $25 \mu \mathrm{l}$. Komposisinya adalah sebagai berikut: Master Mix PCR 12,5 $\mu \mathrm{L}, 2,5 \mu \mathrm{L}$ pasangan primer fim- $\mathrm{C}$, nuclease free water $9 \mu \mathrm{L}$, dan sampel DNA genom bakteri $1 \mu \mathrm{L}$ dimasukkan ke dalam tabung PCR dan dihomogenisasi. Selanjutnya tabung berisi campuran dimasukkan ke dalam mesin thermal cycle dengan kondisi pemanasan awal pada suhu $95^{\circ} \mathrm{C}$ selama 5 menit, denaturasi pada suhu $95^{\circ} \mathrm{C}$ selama 1 menit, annealing pada suhu $55,8^{\circ} \mathrm{C}$ selama 1 menit, tahap pemanjangan rantai pada suhu $72^{\circ} \mathrm{C}$ selama 1 menit, dan tahap pemantapan produk pada suhu $72^{\circ} \mathrm{C}$ selama 7 menit, dengan jumlah siklus sebanyak 35 siklus dan dilakukan pada suhu ruang $\left(25^{\circ} \mathrm{C}\right)$.

Hasil amplifikasi kemudian dikarakterisasi dengan elektroforesis gel agarosa $2 \%$ dengan pewarna etidium bromida $0,1 \%$. Proses 


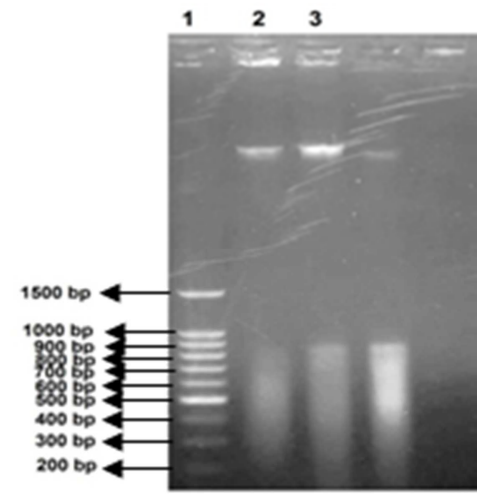

Gambar 1.Karakterisasi Hasil Isolasi DNA Genom Bakteri S. typhimurium. Elektroforesis dilakukan dengan gel agarosa $1 \%$ dan well berisi 1 . Marker ( 5 $\mu \mathrm{L}$ Ladder), 2. S. typhi (5 $\mu \mathrm{L}), 3$. S. typhimurium (5 $\mu \mathrm{L})$.

elektroforesis dilakukan pada kondisi 80 volt selama 1 jam. Visualisasi hasil elektroforesis dilakukan di bawah lampu UV dengan panjang gelombang $260 \mathrm{~nm}$. Setelah itu, gen fim-C hasil amplifikasi dengan PCR dipurifikasi mengikuti kit PCR purification dari promega. Hasil purifikasi kemudian disimpan pada suhu $4{ }^{\circ} \mathrm{C}$ sampai $-20^{\circ} \mathrm{C}$ dan diarakterisasi dengan elektroforesis gel agarosa $2 \%$ dengan pewarna etidium bromida 0,1\%. Proses elektroforesis dilakukan pada kondisi 80 volt selama 1 jam. Visualisasi hasil elektroforesis dilakukan di bawah lampu UV dengan panjang gelombang $260 \mathrm{~nm}$.

Kloning Gen fim-C dengan Ukuran 0,7 Kilobasa Ligasi Produk PCR Gen fim-C dengan Vektor pGEM-T easy

Reaksi ligasi dilakukan sesuai prosedur kit vektor pGEM-T easy. Jumlah vektor dan DNA hasil PCR yang digunakan dalam reaksi ligasi diambil sesuai dengan rasio perbandingan molar yang dianjurkan pada kit. Rasio perbandingan molar sisipan : vektor adalah 3 : 1. Ukuran vektor pGEM-T easy $3 \mathrm{~kb}$ dan ukuran sisipan gen fim-c $S$. typhimurium $0,7 \mathrm{~kb}$. Berdasarkan perbandingan molar dengan rumus dari kit pGEM-T easy untuk reaksi ligasi menggunakan 50 ng vektor, jumlah sisipan yang harus ditambahkan adalah 35ng. Reaksi dilakukan dalam tabung eppendorf 1,5 mL dengan mencampurkan $5 \mu \mathrm{L}$ bufer ligasi $2 x \mathrm{~T} 4$ DNA ligase; $1 \mu \mathrm{L}$ (50 ng) vektor pGEM-T easy; $1 \mu \mathrm{L}$ enzim T4 DNA ligase $3 \mathrm{u} / \mu \mathrm{L} ; 3 \mu \mathrm{L}$ (35ng) hasil PCR yang telah dimurnikan dengan presipitasi etanol. Volume akhir campuran dibuat menjadi $10 \mu \mathrm{L}$. Campuran dihomogenkan dengan pipet, dilanjutkan dengan inkubasi pada $4^{0} \mathrm{C}$ selama semalam. Hasil reaksi ligasi dapat disimpan pada suhu 2$8^{\circ} \mathrm{C}$ sampai akan digunakan.

Transformasi E.coli TOP10 dengan Hasil Ligasi

E.coli TOP10 selanjutnya ditransformasi dengan hasil ligasi. Sebelum dilakukan transformasi, E.coli TOP10 harus dipersiapkan menjadi kompeten sel agar mempunyai efisiensi yang tinggi dalam menerima DNA dari luar pada proses transformasi. Transformasi E.coli TOP10 dengan hasil ligasi dilakukan dengan metode kejut panas. Setelah itu dilakukan skrining koloni putih-biru. Koloni yang diduga positif (koloni putih) lalu di ambil dan dikultur dalam media LB-ampisilin cair untuk selanjutnya diekstrak plasmidnya.

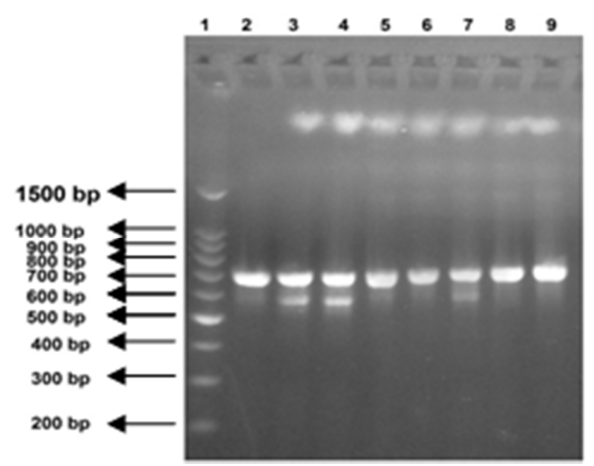

Gambar 2 Hasil Amplifikasi S.typhimurium dengan Variasi Suhu Annealing. Hasil amplifikasi dikarakterisasi dengan elektroforesis gel agarosa $2 \%$ dan variasi suhu annealing yang digunakan 1. Marker; 2. Suhu 680C; 3. Suhu 66,80C; 4. Suhu 64,60C; 5 . Suhu 60,60C; 6 . Suhu 55,80C; 7. Suhu 51,90C; 8 . Suhu 49,30C; 9.Suhu 48,00C. 
Karakterisasi Hasil Transformasi dengan Size Screening

Koloni putih dan biru yang dihasilkan dari hasil transformasi dipindahkan ke dalam media agar LB dan diinkubasi $37^{\circ} \mathrm{C}$ selama 16 18 jam. Beberapa koloni putih dan biru diambil dengan tusuk gigi steril dan dimasukkan ke dalam $25 \mu \mathrm{L}$ rapid distruption solution. Setelah itu, dipanaskan dalam air mendidih selama 5 menit lalu disentrifugasi 12000rpm selama 5 menit. Kemudian dirunning dalam gel agarosa $1 \%, 80$ volt, 30 menit.

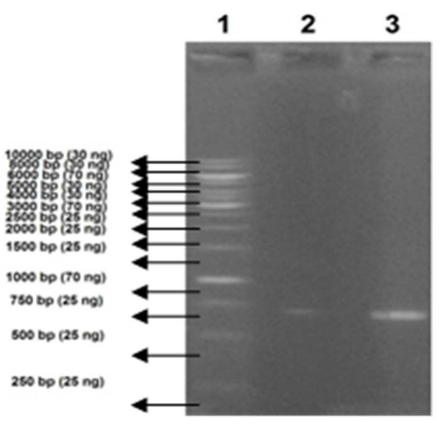

Gambar 3 Hasil Purifikasi Gen fim-C S.typhimurium dengan Ladder $1 \mathrm{~kb}$. Hasil purifikasi dikarakterisasi dengan elektroforesis gel agarosa $1 \%$ dan well berisi 1.Marker; 2. Hasil purifikasi gen fim-C S.typhi; 3. Hasil purifikasi S.typhimurium.

Isolasi Plasmid Rekombinan

Isolasi DNA plasmid sel transforman dilakukan dengan menggunakan High-Speed Plasmid Kit. Karakterisasi hasil isolasi dilakukan dengan elektroforesis gel agarosa $1 \%$ dengan pewarna etidium bromida $0,1 \%$. Proses elektroforesis dilakukan pada kondisi 80 volt selama 30 menit. Visualisasi hasil elektroforesis dilakukan di bawah lampu UV.

Karakterisasi Hasil Isolasi Plasmid dengan Analisis Restriksi

Karakterisasi hasil kloning dilakukan dengan enzim restriksi Enzim restriksi yang digunakan adalah BamH I dan Hind III. Analisis dilakukan dalam $10 \mu \mathrm{L}$ campuran reaksi yang berisi $5 \mu \mathrm{L}$ fragmen DNA gen fim-C $S$. typhimurium hasil kloning, 0,1 $\mu \mathrm{L} \mathrm{BamH} \mathrm{I,} \mathrm{0,1}$ $\mu \mathrm{L}$ Hind $I I I, 1 \mu \mathrm{L}$ stok buffer enzim (sesuai dengan enzim yang digunakan dan berasal dari produsen enzim yang bersangkutan), dan nuclease free water sebanyak $3,8 \mu \mathrm{L}$. Inkubasi untuk pemotongan sempurna DNA dengan enzim dilakukan pada temperatur $37^{\circ} \mathrm{C}$ selama semalam. Hasil pemotongan DNA dengan enzim restriksi tersebut selanjutnya dianalisis dengan metode elektroforesis gel agarosa $1 \%$. Proses elektroforesis dan visualisasi hasil dilakukan sama dengan tahap sebelumnya.

Analisis Sekuen DNA Gen fim-C

Analisis sekuen DNA gen fim-C dilakukan untuk mengetahui sekuen gen target telah terfusi his-tag. DNA target disekuensing dengan menggunakan sekuenser (Applied Biosystem Instrument).

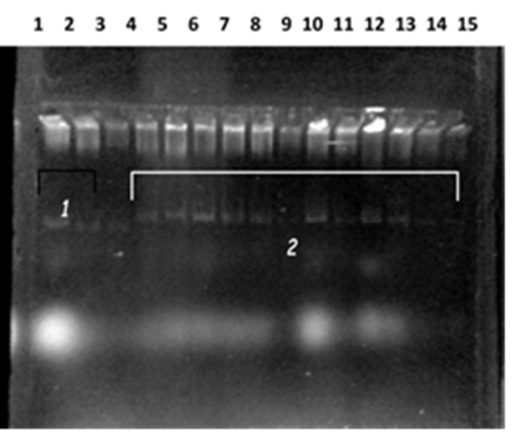

Gambar 4 Hasil size screening. Karakterisasi size screening dilakukan dengan elektroforesis gel agarosa 1\% dan well berisi 1) Koloni biru; 4-15)

Koloni putih. Dari hasil elektroforesis dapat diketahui ada perbedaan ukuran antara pita koloni biru (1) dengan pita koloni putih (2).

\section{HASIL DAN PEMBAHASAN}

Perancangan Primer Spesifik Gen fim-C Salmonella typhi

Perancangan primer spesifik gen fim- $\mathrm{C}$ S.typhimurium digunakan program DNAstar. Pada perancangan primer disisipkan urutan enzim BamHI pada ujung 5' dan enzim HindIII pada ujung $3^{\prime}$. Hal ini untuk memudahkan pemotongan hasil subkloning dengan vektor ekspresi pada penelitian selanjutnya. Hasil dari perancangan primer didapatkan sepasang primer forward dan primer reverse disajikan 
pada tabel 1. Primer yang telah didapatkan kemudian digunakan dalam proses amplifikasi gen fim-C bakteri S. typhimurium.

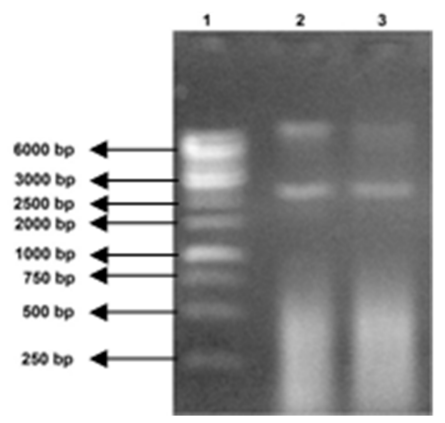

Gambar 5 Hasil Isolasi Plasmid Rekombinan. Hasil isolasi plasmid rekombinan dikarakterisasi gel agarosa $1 \%$ dengan well berisi 1 . Marker; 2 . Hasil isolasi plasmid koloni 12; 3. Hasil isolasi plasmid koloni 16.

Penumbuhan Biakan Bakteri S. typhimurium

Penumbuhan biakan bakteri Salmonella typhimurium pada media cair (Nutrient Broth) telah berhasil dilakukan. Tumbuhnya bakteri ditandai dengan keruhnya media pertumbuhan dibandingkan dengan media Nutrient Broth steril. Makin keruh media menunjukkan bakteri dapat tumbuh dengan baik pada media. Kultur bakteri hasil penumbuhan pada media NB, kemudian dibiakkan pada media Nutrient Agar (NA) selama 24 jam pada suhu $37^{\circ} \mathrm{C}$ dan didapatkan hasil yang menunjukkan terbentuknya kolonikoloni tunggal dari S. typhimurium.

Isolasi Genom Bakteri S. typhimurium dan Karakterisasinya dengan Elektroforesis

Isolasi DNA genom bakteri Salmonella typhimurium dilakukan dengan kit isolasi Wizard. DNA genom bakteri hasil isolasi selanjutnya dikarakterisasi dengan elektroforesis gel agarosa $1 \%$. Hasil elektroforesis disajikan pada gambar 1 . Berdasarkan hasil elektroforesis diketahui bahwa DNA genom bakteri S.typhimurium telah berhasil diisolasi. Hal ini ditandai dengan munculnya pita-pita DNA pada gel. Adanya 2 pita dengan ukuran lebih dari $2 \mathrm{~kb}$ menunjukkan bahwa $S$. typhimurium berbentuk sirkular. Hasil ini sesuai dengan literatur yang menunjukkan bahwa ukuran DNA genom S.typhimurium sebesar 4,81 mega base pairs (mb) [3].

Amplifikasi Genom Bakteri S. typhimurium dengan Primer yang Spesifik dan Karakterisasinya dengan Elektroforesis

Proses amplifikasi PCR dengan pasangan primer fimC-Stpm-F dan fimC-Stpm- $R$ yang menggunakan templat DNA genom bakteri S.typhimurium telah berhasil memperoleh amplikon berukuran 0,7 kb. Proses amplifikasi S.typhimurium dilakukan dengan variasi suhu annealing mulai dari $48 \circ \mathrm{C}-68 \circ \mathrm{C}$. Hal ini bertujuan untuk mengetahui suhu annealing (penempelan) primer secara optimum. Hasil amplifikasi gen fim-C S. typhimurium dapat dilihat dari hasil elektroforesis dengan agarosa $2 \%$ pada gambar 2 .

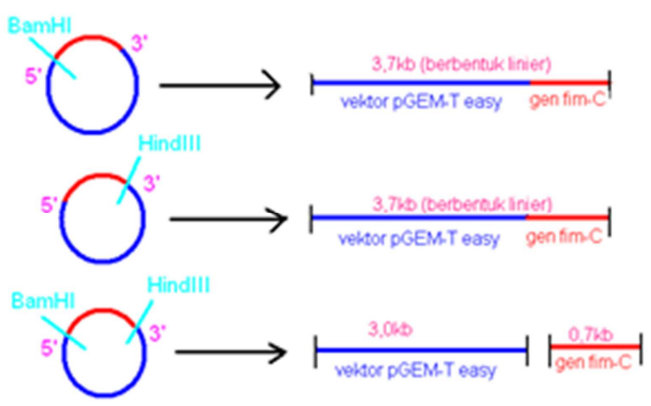

Gambar 6 Gambaran hasil analisis restriksi plasmid rekombinan pGEM-fimC S.typhimurium. Analisis teoritis menunjukkan plasmid rekombinan pGEMfimC S.typhimurium dapat dipotong dengan enzim restriksi BamHI dan Hind III.

Dari hasil elektroforesis diketahui bahwa suhu optimum annealing (penempelan) primer terhadap templat DNA S.typhimurium adalah $60,6^{\circ} \mathrm{C}$ dan didapatkan hasil ampifikasi S.typhimurium dengan panjang fragmen 0,7 $\mathrm{kb}$. Gel agarosa hasil elektroforesis yang berisi templat hasil PCR berukuran $0,7 \mathrm{~kb}$, kemudian dimurnikan dengan menggunakan kit purifikasi. Hasil pemurnian dari bakteri tersebut kemudian ditentukan konsentrasinya 
dengan elektroforesis menggunakan ladder $1 \mathrm{~kb}$. Purifikasi dilakukan untuk memurnikan DNA bakteri dari gel agarosa. Karakterisasi hasil purifikasi dilakukan dengan elektroforesis gel agarosa $1 \%$. Foto hasil amplifikasi S.typhimurium dan hasil purifikasi disajikan pada gambar 3 .

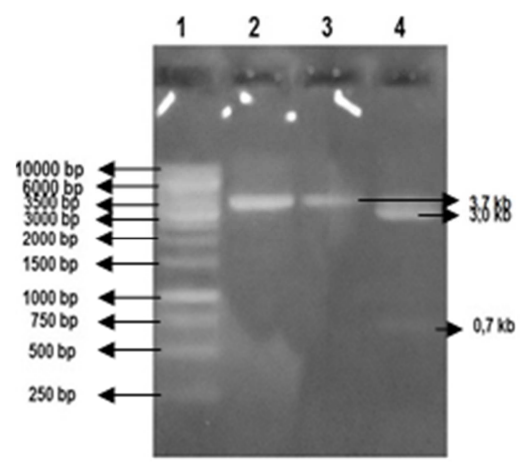

Gambar 7 Hasil Analisis Restriksi Plasmid Rekombinan fim-C S.typhimurium. 1. Marker; Hasil pemotongan plasmid koloni 12 dengan enzim restriksi 2. BamHI; 3. HindIII; 4. BamHI dan HindIII.

Dari hasil elektroforesis dapat diketahui bahwa intensitas pita yang timbul (1) setara dengan pita 750bp yang mempunyai konsentrasi 70 ng. Namun, karena volume gen yang di running adalah $2 \mu \mathrm{L}$ sehingga konsentrasi dari gen fim-C S.typhimurium sebesar $35 \mathrm{ng} / \mu \mathrm{L}$.

Kloning Gen Fim-C Salmonella

typhimurium dengan Ukuran 0,7 Kilobasa

dan Karakterisasinya

Kloning gen fim-C S.typhimurium dilakukan melalui beberapa tahap, yaitu 1) ligasi gen fimC dengan vektor pGEM-T easy; 2) Transformasi bakteri E.coli TOP10 dengan hasil ligasi ; 3) Karakterisasi hasil transformasi dengan size screening; 4) Isolasi plasmid rekombinan; 5) Karakterisasi hasil isolasi plasmid dengan elektroforesis gel dan analisis restriksi; 6) Sekuensing hasil kloning gen fim-C S.typhimurium dengan vektor kloning pGEM-T easy. Tahapan kloning dilakukan dengan tujuan memperbanyak gen fim-C S.typhimurium yang pada penelitian selanjutnya akan disubkloning ke vektor

ekspresi sehingga didapatkan protein dari gen fim-C S.typhimurium.

Ligasi Gen Fim-C S.typhimurium dengan vektor pGEM-T easy

Reaksi ligasi dilakukan sesuai prosedur kit vektor PGEM-T easy. Hasil purifikasi amplifikasi produk PCR fim-C yang telah didapat selanjutnya dijadikan sebagai insert dalam proses ligasi ke vektor kloning. Vektor kloning yang digunakan dalam penelitian ini adalah plasmid PGEM-T easy. Penggunaan vektor pGEM-T easy memiliki beberapa keuntungan, antara lain adalah plasmid ini merupakan plasmid linear yang mempunyai basa Timin ( $T$ ) menggantung (overhangs) pada kedua ujungnya. Daerah T-overhangs pada situs pemasukan insert ini meningkatkan efesiensi ligasi untuk produk PCR karena mencegah terjadinya resirkularisasi (melingkar kembali) vektor sebelum penempelan insert. Insert yang merupakan produk PCR hanya perlu diberi perlakuan sederhana untuk menambahkan basa Adenin (A) pada ujungnya atau biasa disebut dengan A-tailing agar bisa menempel pada daerah T-overhangs vektor tanpa harus memotongnya terlebih dahulu dengan enzim restriksi.

AAGCTTTCATGAAGCTGGACAAACGCGTGCTGGCGTCGTTGCGCCAAAAT CGTTTACCGTGCGCAAAGATACCTGGCCGGGCGTCGCCGGGAGAGTGATC GCGCCTTTCGGCGGTACCATAGTATTCGGCAGTTTTTTCCCCGCGCTATACA GTTCAACCATCGAAACGTAGTACGGCGAAGGGTTAGTAATCGTTAGCTGGC CGCGCTCGTTACGGCAGCGAAGCGTCGACGGGGCATGAGCTGGCGCCTCC GCCAGATTTTTCGGGCGGATAAATAGCTTAATCACGCTTTGCGTCGCAATTT GCAGGGAGTTGCCGGTCAATTTATTTTTATCGACAGAGGGTATCGTTTTACT GTTTAAATAAAATACGCTTTCGCGATCGGTCGGTAATGACGGCCCGACATAC ATAATACGTAATATATTTTCTTTTTTAGGCTGGATCACAAAGAGAGGCGGCGT AATGATAAAATCCGTCGAGCGTGAACCATCGGCATTGGCGACCCATGACTG AATTAAAAAAACATTGCTGGCAGAAGAATTAATAATCGGCAAGGAGGTTTGC TTACTTCCCTGCGGATAAATCACCCTGGTCGCGCCCAGCGCAATGCCTCCC GCCTGCGCGGCAAACGACAGGCCGGCCGCCGACAGCAGTAGCAATAATCG AAGGAAAATCGGTACGTTTTTTTTGGATCC

Gambar 8 Hasil Sekuensing Klon 12 dari Daerah Primer Reverse Hingga Daerah Primer Forward. Urutan nukleotida yang diberikan warna merah dan digaris bawahi merupakan daerah primer yang sesuai setelah dicocokkan dengan urutan primer yang digunakan pada saat amplifikasi gen fim-C. 
Transformasi Bakteri E.coli TOP10 dengan Hasil Ligasi

Pada tahap ini telah berhasil dikloning gen fimC S.typhimurium yang dikonstruksikan pada plasmid pGEM-T easy. Hal ini ditunjukkan dengan diperolehnya koloni putih pada media LB X-gal/IPTG. Koloni putih yang diperoleh menunjukkan bahwa vektor pGEM-T easy pada sel transforman E. coli TOP 10 mengandung sisipan berupa fragmen 0,7 kb.

Asumsi tentang keberhasilan proses kloning didasarkan pada: (1) Peta sirkular vektor pGEM-T easy telah diketahui memiliki dua marker yaitu gen LacZ dan gen resisten ampisilin. Masuknya sisipan DNA 0,7 kb akan memotong urutan gen LacZ, sehingga gen tersebut tidak menghasilkan enzim? $\beta$ galaktosidase yang dapat menguraikan substrat mirip laktosa yaitu X-gal (5-bromo-4kloro-3-indoil- $\beta$-D-galaktopiranosida) dengan bantuan inducer IPTG (isopropil- $\beta-D-$ galaktopiranosida) menjadi galaktosa dan substansi berwarna biru (5-bromo-4kloroindigo). Terpotongnya urutan gen LacZ menyebabkan sel inang tidak menghasilkan enzim [3-galaktosidase dan akhirnya X-gal pada medium tidak dapat diubah menjadi senyawa biru, (2) E. coli TOP 10 yang digunakan sebagai sel inang pada proses kloning diketahui memiliki sifat sensitif terhadap ampisilin, berdasarkan hasil yang diperoleh ternyata sel inang yang ditransformasi dengan vektor pGEM-T rekombinan dapat hidup pada media yang mengandung ampisilin. Kontrol negatif terhadap sel inang yang tidak ditransformasi dengan plasmid rekombinan menunjukkan sel inang tersebut tidak dapat tumbuh pada media yang mengandung ampisilin. Berdasarkan fenomena tersebut disimpulkan telah berhasil dilakukan proses kloning gen fimC S.typhimurium yang dikonstruksikan pada vektor pGEM-T easy dalam sel inang E.coli TOP 10. Untuk memastikan bahwa koloni putih benar ada insert nya maka dilakukan size screening. Size screening ini merupakan suatu cara untuk memastikan bahwa terdapat insert dalam plasmid dengan membandingkan ukuran plasmid koloni biru dan ukuran plasmid koloni putih. Pada size screening ini digunakan rapid distruption solution yang melisis sel sehingga didapatkan plasmid rekombinannya. Perbandingan ukuran plasmid diketahui dengan elektroforesis gel agarosa 1 $\%$. Foto hasil size screening antara koloni putih dan biru disajikan dalam gambar 4 .

AAGCTTTCATGAAGCTGGACAAACGCGTGCTGGCGTCGTTGCGCCAAAAT
CGTTTACCGTGCGCAAAGATACCTGGCCGGGCGTCGCCGGGAGAGGATC
GCGCCTTTCGGCGGTACCATAGTATTCGGCAGTTTTTCCCCGCCTATACA
GTTCAACCATCGAAACGTAGTACGGCGAAGGGTTAGTATCGTTAGCTGGC
CGCGCTCGTTACGGCAGCGAAGCGTCGACGGGCATGAGCTGGCGCTCC
GCCAGATTTTTCGGGCGGTAAATAGCTTAATCACGCTTTGCGTCGCAATTT
GCAGGGAGTTGCCGGTCAATTTATTTITATCGACAGAGGGATCGCTTTACT
GTTTAAATAAAATACGCTTTCGCGATCGGTCGGTAATGACGGCCCACATAC
ATAATACGTAATATATTTCTTTITAGGCTGGATCACAAAGAGAGGCGGCGT
AATGATAAAATCCGTCGAGCGTGAACCATCGGCATTGGCGACCCATGACTG
AATTAAAAAAACATTGCTGGCAGAAGAATTAATAATCGGCAAGGAGGTTTCC
TTACTTCCCTGCGGATAAATCACCCTGGTCGCGCCCAGCGCAATGCCTCCC
GCCTGCGCGGCAAACGACAGGCCGGCCGCCGACAGCAGTAGCAATAATCG
AAGGAAAATCGGTACGTTTTTTTTGGATCC

Gambar 9 Hasil Sekuensing Klon 16 dari Daerah Primer Reverse Hingga Daerah Primer Forward. Urutan nukleotida yang diberikan warna merah dan digaris bawahi merupakan daerah primer yang sesuai setelah dicocokkan dengan urutan primer yang digunakan pada saat amplifikasi gen fim-C.

Dari hasil elektroforesis terdapat perbedaan ukuran antara pita koloni biru (1) dengan pita koloni putih (2). Adanya perbedaan ukuran pita disebabkan karena pada koloni biru tidak terdapat insert sedangkan pada koloni putih terdapat insert sehingga ukuran fragmen semakin bertambah. Hal ini menandakan bahwa pada koloni putih benar terdapat insert gen fim-C pada vektor pGEM-T easy.

Isolasi Plasmid Rekombinan

Isolasi plasmid rekombinan dari dua koloni putih hasil transformasi yaitu koloni nomor 6 dan 7 yang dilakukan dengan kit High Speed Plasmid telah berhasil dilakukan. Hasil dari isolasi plasmid rekombinan ini divisualisasikan dengan elektroforesis dan disajikan pada gambar 5 . 
Berdasarkan data hasil elektroforesis yang disajikan pada gambar 5 diketahui bahwa plasmid rekombinan telah berhasil diisolasi. Hal ini ditandai dengan munculnya pita-pita DNA pada gel. Untuk memastikan terdapatnya insert pada plasmid pemotongan yaitu dengan BamH I saja, Hind III saja, dan dengan keduanya (double digest). Secara teoritis enzim restriksi BamH I akan memotong plasmid pGEM-rekombinan pada satu sisi dengan sisi pengenal G $\downarrow$ GATCC pada bagian 5', enzim restriksi Hind III akan memotong pada satu sisi dengan sisi pengenal $\mathrm{A} \downarrow$ AGCTT pada bagian 3'. Sehingga masing-masing hasil pemotongan tersebut akan menghasilkan satu pita dengan ukuran 3700 pb. Pemotongan klon rekombinan dengan dua enzim restriksi (doubel digest) secara bersamaam akan menghasilkan 2 pita yang masing-masing berukuran $3000 \mathrm{pb}$ (ukuran vektor pGEM-T easy) dan 700 pb (ukuran gen fim-C S. typhimurium). Gambaran hasil analisis restriksi secara teoritis dapat dilihat pada gambar 6 .

Analisis Pemotongan enzim restriksi secara eksperimen dilakukan sesuai petunjuk dari promega. Hasil eksperimen menunjukkan pemotongan plasmid pGEM-rekombinan dengan Enzim BamH I dan enzim Hind III menghasilkan masing-masing satu pita berukuran 3,7 kb. Hasil pemotongan enzim BamH I dan Hind III secara doubel digest menghasilkan dua pita DNA dengan ukuran 3 $\mathrm{kb}$ vektor pGEM-T easy dan $0,7 \mathrm{~kb}$ gen fimC. Adanya 2 pita dengan ukuran $3,0 \mathrm{~kb}$ dan $0,7 \mathrm{~kb}$ membuktikan bahwa terdapat insert yang pada vektor pGEM-T easy sesuai analisis restriksi secara teoritis. Foto visualisasi hasil pemotongan secara eksperimen dengan elektroforesis gel agarosa disajikan dalam gambar 7.

Sekuensing Urutan Nukleotida Gen fim-C Hasil Kloning Bakteri Salmonella typhimurium

Hasil isolasi plasmid dari isolat E.coli TOP10 rekombinan klon 12 dan klon 16 yang berisi insert gen fim- $\mathrm{C}$ telah berhasil disekuensing di Macrogen, Korea. Sekuen gen fim-C klon 12 dalam bentuk FASTA disajikan pada gambar 8 sedangkan sekuen gen fim- $C$ klon 16 disajikan pada gambar 9. Tanda yang digaris bawahi dan diberi warna merah pada sekuen adalah daerah primer yang sesuai setelah dicocokkan dengan urutan primer yang digunakan pada saat amplifikasi gen fimC. Hasil sekuensing menunjukkan bahwa telah berhasil didapatkan pGEM-fimC S.typhimurium yang ditandai dengan adanya daerah primer pada hasil sekuen. Untuk menganalisis homologi hasil sekuensing diambil dari daerah primer forward sampai daerah primer reverse. Hasil sekuen menunjukkan bahwa terdapat kesamaan $100 \%$ diantara dua urutan sekuen tersebut. Analisis homologi dilakukan dengan program BLAST (www.ncbi.nlm.nih.gov) pada 17 Juli 2012. Hasil BLAST menunjukkan gen fim-C hasil kloning memiliki homologi sebesar $100 \%$ dengan urutan nukleotida gen fim-C $S$. typhimurium Lt2 yaitu pada urutan nukleotida gen fim-C S.typhimurium Lt2. Hasil penelitian ini selanjutnya dijadikan sebagai acuan untuk penelitian berikutnya dalam rangka penemuan vaksin rekombinan untuk pencegahan penyakit typhus. Hasil kloning dari vektor pGEM-T selanjutnya disubkloning ke vektor $p E T$ untuk memperoleh protein yang nantinya akan dijadikan sebagai vaksin rekombinan.

\section{KESIMPULAN}

Hasil penelitian menunjukkan telah berhasil didapatkan klon rekombinan pGEMfimC S.typhimurium. Klon rekombinan diperoleh dengan cara meligasi gen fim-C dengan vektor pGEM-T easy, mentransformasi bakteri E.coli TOP10 dengan hasil ligasi, mengkarakterisasi hasil transformasi dengan size screening, mengisolasi plasmid rekombinan, dan mengkarakterisasi hasil isolasi plasmid dengan analisis restriksi serta teknik sekuensing. Hasil analisis restriksi pada klon rekombinan menunjukkan telah terdapat 
insert pada vektor pGEM-T easy. Hasil ini diperkuat dengan hasil sekuensing. Hasil sekuensing menunjukkan bahwa telah berhasil didapatkan pGEM-fimC S.typhimurium yang ditandai dengan adanya daerah primer pada hasil sekuen. dan diketahui bahwa gen fim-C ini mempunyai homolog sebesar $100 \%$ dengan S.typhimurium Lt2.

\section{UCAPAN TERIMA KASIH}

Ucapan terimakasih kami haturkan kepada Direktorat P2M Ditjen Dikti yang telah memberikan Hibah Strategis Nasional sehingga Penelitian ini dapat berlangsung. Dessy Natalia, Ph.D, Ikhsanawati, Ph.D dan Dr. Fernita Puspasari dari Laboratorium Biokimia FMIPA ITB atas segala saran dan bantuannya sehingga penelitian dapat berjalan lancar.

\section{DAFTAR PUSTAKA}

[1] Anonim, Promega. 2010. DNA Purification. http://www.promega.com/resources/productguides-and-selectors/protocols-and-applications-guide/dna-purification/\#title7, 3 Februari 2012, pk. 10.59 WIB.

[2] Anonim, WHO. 2011. Diarrhoeal Diseases. http://www.who.int/vaccine_research/diseases/diarrhoeal/en/index7.html, 25 Februari 2011, pk. 11.01 WIB.

[3] Bacmap. 2003. Bacterial Map. http://wishart.biology.ualberta.ca/BacMap/ index.html. $10 \mathrm{Juli}$ 2012, pk. 19. 30 WIB.

[4] Hatta, M. dan Smits, H. L. 2007. Detection of Salmonella typhi by Nested Polymerase Chain Reaction in Blood, Urine, and Stool Samples. Am. J. Trop. Med. Hyg. 76 (1): 139-143.

[5] Leon, R. O., Camilo, J. A., M. Carolina D., Dong, B., Sujit, K. B., Magdarina, D. A., Zulfiqar, A. B., Do, G. C., Mohammad, A., Seonghye, S., John, W., Anne-Laure, P., M. John, A., Jeremy, F., Remon, A., Tikki, P., Claudia, M. G., Lorenz, V. S., John, D. C. 2008. A Study of Typhoid Fever in Five Asian Countries: Disease Burden and Implications for Controls. Bulletin of the World Health Organization. 86 (4): 241-320, http://www.who.int/bulletin/volumes/86/4/06-039818-tableT1.html, 25 Januari 2012, pk. 10.55 WIB.

[6] O'Brien, A. D., Rosenstreich, D. L., Taylor, B. A. 1980. Control of Natural Resistance to Salmonella typhimurium and Leishmania donovani in Mice by Closely Linked but Distinct Genetic Loci. Nature. 287: 440-442. http://www.ncbi.nlm.nih.gov/pmc/articles/PMC2972545, 13 Januari 2012, pk. 22.56 WIB.

[7] QIAPREP. 2000. Instructional manual, Promega.

[8] Rachmayanti dan A. S. Noer. 1998. Modifikasi Metode Isolasi DNA Plasmid sehingga Lebih Sederhana dan Dapat Dilakukan pada Suhu Kamar. Journal The Malaysian of Analitical Science, 4, 277-281.

[9] Thorns, C. J. 1995. Salmonella Fimbriae: Novel Antigens in the Detection and Control of Salmonella Infections. British Veterinary Journal 151: 643-658.

[10] Zhang, S., Robert, A. K., Renato, L. S., Helene, A. P., Manuela, R., Josely, F., Jairo, N., Renee, M. T., Garry, A., dan Andreas, J. B. 2003. Patogenesis Molekuler Salmonella enterica serotipe Diare typhimurium-induced. Infection and Immunity. 71 (1): 1-12.

http://www.ncbi.nlm.nih.gov/pmc/articles/PMC143292/, 3 Januari 2012, pk. 21.16 WIB. 